DOI: 10.34015/2523-4552.2020.4.10

УДК 340.13

Бондаренко $\epsilon$. I., асистентка кафедри конституційного, адміністративного та кримінального права Навчально-наукового інституту «Юридичний інститут Державного вищого навчального закладу «Київський національний економічний університет імені Вадима Гетьмана» ORCID: 0000-0003-0468-7949

\title{
СТАЛІСТЬ СУДОВОЇ ПРАКТИКИ ЯК ОСНОВА РОЗУМІННЯ ДОКТРИНИ ПРАВОВОГО ПРЕЦЕДЕНТУ
}

Досліджується історична основа становлення доктрини правого прецеденту та принципи, що забезпечують його функціонування як джерела права у сучасних правових системах, в тому числі, де він офіційно не визнається. Судовий прецедент аналізується як основа доктрини правого прецеденту та один з його видів.

Ключові слова: правовий прещедент; stare decisis; ratio decidendi; obiter dictuт; джерело права.

Исследуется историческая основа становления доктрины правого прецедента и принципы, обеспечивающие его функционирование как источника права в современных правовых системах, в том числе, где он официально не признается. Судебный прецедент анализируется как основа доктрины правого прецедента и один из его видов.

Ключевые слова: правовой прецедент; stare decisis; ratio decidendi; obiter dictuт; источник права.

Постановка проблеми. Тенденції зближення правових сімей, зумовлені сучасними політичними, економічними та соціальними інтеграційними процеси у світі актуалізують питання юридичної сили різних джерел права, уточнення ролі і місця правового прецеденту серед них та потребують відповідного комплексного дослідження.

У науці правовий прецедент здебільшого розглядався як юридичний феномен притаманний лише тим країнам, правові системи яких розвивались під впливом англійсь- кого права в межах англосаксонської правової сім'ї, ігноруючи при цьому його фактичне існування як джерела права в інших правових системах світу, де він де-факто застосовувався, хоча де-юре не визнавався джерелом права з боку держави, саме ці фактори зумовлюють необхідність переосмислення самої доктрини правового прецеденту.

Аналіз останніх досліджень i публікацій. Дослідженнями окремої проблематики доктрини правового прецеденту займались як вітчизняні так і зарубіжні вчені. Зокрема, ваго- 
мий внесок у розробку цього питання свого часу зробили Е. Дженкс, Р. Уолкер, Дж. Бакер, Б. Кардозо та інші. Серед вітчизняних науковців, які розробляли цю проблематику, на окрему увагу заслуговують праці Т. Г. Андрусяка, Л. А. Луць, Н. М. Оніщенко, Н. М. Пархоменко, П. М. Рабіновича, С. В. Шевчука.

Однак, у зв'язку з усе зростаючою в наш час динамікою суспільних відносин, постійним зближенням правових сімей, посиленням позицій правового прецеденту серед інших джерел права в країнах континентальної правової сім'ї, забезпечення ефективності і стабільності правового регулювання у державі набуває особливої актуальності. Виникає потреба в переосмисленні традиційних юридичних конструкцій та з'ясуванні чинників що впливають на зміну юридичної сили джерел права та забезпечують їх ефективність як правового регулятора.

Постановка завдання. Метою статті $\epsilon$ аналіз доктрини правового прецеденту, з акцентом на історичних аспектах набуття прецедентом рис джерела права, що дозволить встановити його юридичне значення і важливість для правових систем, де він ще офіційно не визнається джерелом права, хоча фактично використовується.

Крім того, потребує дослідження юридична сила правового прецеденту як регулятора правовідносин, з'ясування його ролі та місця серед інших джерел права на сучасному етапі розвитку правових систем європейських держав, шляхом аналізу законодавства та дослідження поглядів науковців різних країн.

Виклад основного матеріалу. На думку української вченої
Н. М. Пархоменко ефективність і стабільність правового регулювання у державі забезпечується та зумовлюється багатьма чинниками й засобами, серед яких одним із найважливіших є передбачуваність, прогнозованість та сталість судової практики. Саме завдяки цьому реалізуються засадничі принципи правової держави - верховенство права, правова визначеність, законність, рівність усіх перед законом і судом. При цьому зазначається, що сталість судової практики як чинник правового регулювання визначається насамперед її єдністю [1, с. 26]. Потрібно погодитись, що саме дотримання принципу єдності судової практики необхідно розуміти як початок, ідею, що забезпечує судам одноманітне застосування нормативних правових актів та їх тлумачення, здійснене вищими судовими органами при вирішенні аналогічних судових справ.

Як відомо, функціонування прецеденту як джерела права історично базується на принципі stare decisis (від латинського виразу «stare decisis et not quetta movera» - «дотримуватись того, що було вже вирішене, та не турбувати те, що спокійно»), який пов'язаний зі становленням і розвитком сукупності правил обов'язковості доктрини прецеденту, та був сформований безпосередньо в процесі діяльності судів, і $\epsilon$ виразом визнання прецеденту як способу об'єктивації норм права $з$ боку держави [2, с. 147]. Зміцнення цього принципу означає $\mathrm{i}$ закріплення прецеденту як формального джерела права, і утвердження сталості і єдності судової практики.

Принцип stare decisis, який історично склався в умовах англо- 
саксонської правової сім'ї, набуває нового наповнення щодо держав «цивільного права» (континентального права) i пристосовується до вимог сучасного права. Цього принципу, який спочатку передбачав обов'язковість прийняття подальших рішень за зразком попередніх (жорстке дотримання прецедентних норм), нині дотримуються не так суворо навіть в країнах «загального права». Оскільки обов'язковість подальшого використання адміністративних рішень як правового орієнтира при розгляді подібних справ забезпечується авторитетом і професіоналізмом відповідних уповноважених органів.

Як зазначає Т. В. Михайліна, відмінністю прецеденту як джерела права від суміжних правових актів $\epsilon$ його сутнісні ознаки, а зокрема, основою доктрини прецеденту $є$ принцип stare decisis. I найголовніше, що характеризує прецедент як джерело права, це здатність закріпленої в ньому нормі виходити за межі лише ситуації правозастосування та поширюватись на більш широке коло відносин, а також право суддів посилатись в наступних рішеннях безпосередньо на «ядро» відповідного прецеденту - stare decisis, - що в корні відрізняє принципи його застосування від посилання в наступних рішеннях на ту ж саму норму статутного права [3, с. 92].

Слід зазначити, що не все рішення по спірному питанню $\epsilon$ прецедентом, а лише певна частина його структури. Шотландський учений Н. Маккормік писав, що «без теоретичного розуміння прецеденту і таких ключових концепцій, як ratio decidendi, неможливо фактично peалізувати жодну правову доктрину прецеденту» [4]. Зрозуміти суддівське право означає зрозуміти, яким чином відбувається перетворення конкретного рішення окремого судді для конкретної справи в конструкцію загальної норми, що стосується всіх людей.

Отже, у конструкції «англосаксонського» прецеденту виокремлюється особливий елемент ratio decidendi (сутність, мотиви рішення, правова позиція суду або іншого уповноваженого на прийняття рішень органу), який розуміється як правоположення, що застосовується до правових питань, які виникають у зв'язку з установленими судом фактами, на яких засновано рішення. Ratio decidendi можна розглядати як «... будь-яку норму права, яка прямо чи опосередковано тлумачиться та використовується суддею як необхідний крок для прийняття рішення, включаючи хід його міркувань або обов'язкову частину його вказівки присяжним» [4, с. 88], або як точку зору, якої мають дотримуватися юристи-практики в їх повсякденній роботі; зобов'язуюче твердження, сформульоване при розгляді справи певного правового питання. Саме у вигляді ratio decidendi прецедентна правова норма отримує своє оформлення, вираження зовні.

Необов'язкову частину рішення в англійській юриспруденції прийнято називати obiter dictum («попутно сказане»), основним завданням якої $\epsilon$ формулювання додаткових доказів для обгрунтування правильності винесеного рішення, пояснення суті правової позиції.

На думку Р. Уолкера, якщо Палата лордів встановлює певну норму і прямо відкидає рішення, що суперечать цій нормі, то положення, що 
було викладене, буде вважатися обов'язковим, навіть якщо воно не становить підстави рішення. Тобто фактично в деяких випадках відмінність між ratio decidendi i obiter dictum практично стирається, точніше obiter dictum може мати те саме значення, що і прецедент з переконливою силою; «... відмінність між переконливим прецедентом і obiter dictum майже збігається 3 відмінністю між обов'язковим і переконливим прецедентами» [5, с. 161].

Відмінності між обов'язковою (яка утворює «тіло» прецеденту) i необов'язковою частинами рішення досить розмиті і викликають масу думок як у науці, так і на практиці. Підстави для їх розмежування часто тлумачаться залежно від вигоди зацікавленої в результаті справи особи, тому було б бажано встановити для уповноважених органів такі правила підготовки текстів рішень, які б допомогли вирішити проблему ідентифікації суті правової позиції, що становить основу прецеденту і вносить новизну в регулювання правових відносин [6, с. 49].

Особливості застосування прецедентного права зводяться до того, що судові рішення, які визнаються прецедентними, відіграють подвійну роль. По-перше, судовими рішеннями вирішується конкретний спір; подруге, в їх змісті закріплюються певні особливості, не обумовлені законом, оскільки всі без винятку випадки людських стосунків неможливо передбачити законодавством [3, с. 92].

Цікавою є практика Європейського суду з прав людини (далі ЄСПЛ) щодо застосування принципу stare decisis, український вчений С. Шевчук, посилаючись на до- сліджуючи це питання зазначає, що ЄСПЛ ніколи безпосередньо не посилається на доктрину stare decisis, але формула, яку він використовує, а саме «відповідно до незмінної судової практики» або «відповідно до усталеного прецедентного права», як і посилання та цитування попередніх судових рішень, підтверджує фактичне наслідування подібної доктрини в його практиці. Для того щоб ЄСПЛ слідував своїм попереднім прецедентам, потрібна їх подібність. 3 цією метою ЄСПЛ застосовує «техніку розрізнень», аби переконатися, що подібні рішення пов'язані між собою [7, с. 124].

Особливості застосування принципу stare decisis можна зайти у практиці не тільки тих судів, що належать до різних правових систем, а навіть і в межах окремої, як от відмінності прецедентного права США та Англії. Однак, досліджуючи доктрину прецеденту, можна виокремити і загальні характерні риси, властиві як «англосаксонському», так і «континентальному» правовому прецеденту, що дозволяють зараховувати їх до одного й того самого виду правових явищ.

У першу чергу слід зазначити, що, безумовно, ні суд, ні будь-який інший орган не має права підміняти законодавця в демократичній правовій державі. Закон встановлює правові основи, принципи регулювання найбільш важливих сфер суспільного життя, очолює ієрархічну систему джерел права. Правовий прецедент, підкоряючись принципу пріоритету закону і в його рамках, виправляє недоліки правового регулювання суспільних відносин. У таких випадках прецедент виконує функції щодо забезпечення 
стабільності сформованого правопорядку.

Прецедент створюється вищими інстанціями в ієрархії судів або органів виконавчої влади, 3 чого випливає, що з метою впорядкування правозастосовчої практики та забезпечення поваги авторитету й професіоналізму вищестоящих органів, слід дотримуватися принципу обов'язковості прийняття подальших рішень згідно виробленим правозастосовчою практикою найбільш прийнятним зразкам [3, с. 90].

Висновки. Різноманіття причин виникнення права, форм його об'єктивації приводять до висновку, що перелік джерел права не може обмежуватися тільки законодавством, а практичне застосування правового прецеденту стає необхідною формою правотворчості, що забезпечує адаптивність права до потреб суспільства та динаміки його розвитку. Доктрина правового прецеденту грунтується на принципі stare decisis, реалізація якого заснована на визначенні ratio decidendi i obiter dictum кожного конкретного прецеденту.
Норма права міститься не в усьому тексті рішення, а лише в тій його частині, яка включає мотиви ухвалення рішення і правову позицію органу, уповноваженого на створення прецеденту (за аналогією 3 ratio decidendi «англо-американського» прецеденту). Інформація про тексти, які містять прецедентні норми, повинна бути загальнодоступною, публікуватись у відповідних засобах масової інформації.

Дослідивши доктрину правового прецеденту потрібно відзначити, що прецедент $\epsilon$ родовим поняття, оскільки у сучасній юридичній діяльності можна виділити судовий, адміністративний та інші види прецедентів, тому доречно розглядати прецедент як фактичний зразок для регулювання наступних аналогічних правовідносин, як результат вирішення справи правозастосовчим органом, який містить юридичний принцип (stare decisis) обов'язковий для застосування при вирішенні однорідних справ в майбутньому.

\section{Список використаних джерел}

1. Пархоменко Н. М. Єдність судової практики як складова правового регулювання. Часопис Київського університету права. 2020. № 3. С. 26-30.

2. Шевчук С.В. Прецедентне право Європейського Суду з прав людини та доктрина stare decisis. Право України. 2010. № 10. С. 147-157.

3. Міхайліна Т. Аспекти співвідношення правового прецеденту та судової практики у контексті правосвідомості. Журнал східноєвропейського права. 2017. № 45. С. 88-96.

4. Cross R. Precedent in English Law. Clarendon Press. 1991. 256 p.

5. Walker R. J. The English legal system. London : Butterworth, 1970.536 p.

6. Derham D. P. Precedent and the Decision of Particular Questions. The Law Quarterly Review. Vol. 79. January 1963. P. 49.

7. Шевчук С. Узгодженість практики Європейського суду з прав людини та Конституційного Суду України. Вісник Конституційного Суду Украӥни. 2011. № 4-5. C. 122-130. 


\section{References}

Parkhomenko, N. M. (2020) Unity of judicial practice as a component of legal regulation. Journal of Kyiv University of Law, 3 [in Ukrainian].

Shevchuk, S.V. (2010) Case law of the European Court of Human Rights and the doctrine of stare decisis. Law of Ukraine, 10 [in Ukrainian].

Mikhailina, T. (2017) Aspects of the relationship between legal precedent and case law in the context of legal awareness. Journal of Eastern European Law, 45 [in Ukrainian].

Cross, R. (1991) Precedent in English Law. Clarendon Press.

Walker, R. J. (1970) The English legal system. London: Butterworth.

Derham, D. P. (1963) Precedent and the Decision of Particular Questions. The Law Quarterly Review, 79. January.

Shevchuk, S. (2011) Consistency of the practice of the European Court of Human Rights and the Constitutional Court of Ukraine. Bulletin of the Constitutional Court of Ukraine, 4-5, 122-130 [in Ukrainian].

Ye. Bondarenko, Assistant of the Department of Constitutional, Administrative and Criminal Law, Institute of Law, SHEI «Vadym Hetman Kyiv National Economic University»

ORCID: 0000-0003-0468-7949

\section{Consistency of judicial practice as the basis for understanding the doctrine of legal precedent}

The article deals with the analyse of the doctrine of legal precedent, with an emphasis on the historical aspects of the acquisition of precedent features of the source of law, which will establish its legal significance and importance for legal systems where it is not yet officially recognized as a source of law.

In addition, the study of the legal force of legal precedent as a regulator of legal relations, clarifying its role and place among other sources of law at the present stage of development of legal systems of European countries, by analyzing legislation and studying the views of scholars from different countries.

A review of scientific researches on this topic indicates that in different periods the problem of the legal force of the legal precedent has always been in the focus of attention of domestic and foreign scientists. The legal precedent is a complex concept that contains the result of a decision of a case by a law enforcement body, which contains a legal principle (stare decisis) that is mandatory for use in solving similar cases in the future, that is, in fact, it is a kind of model for regulating subsequent similar legal relations.

The legal precedent is a general concept, since in legal activity it is possible to distinguish judicial, administrative and other precedents, because the need for precedent regulation is based on the dynamism of social life and the needs of the adaptability of the law.

Keywords: legal precedent; stare decisis; ratio decidendi; obiter dictum; source of law. 